\title{
After Krüger: observations on some additional or revised Justinian Code headings and subscripts")
}

Der Beitrag stellt Ausschnitte aus Handschriften zusammen, die seit der Ausgabe des Codex Justinians 1877 durch Krüger entdeckt wurden, und die Ergänzungen oder Korrekturen an Inskriptionen und Subskriptionen ermogglichen. Die Handschriften sind P. Oxy. XV 1814 (C. 1,11,1-1,16,11 [first edition]), MS Cologne GB Kasten B no. 130 (C. 3,32,4-12), PSI XIII 1347 (C. 7,16,41-7,17,1), P. Rein. Inv. 2219 (fragments of C. 12,59,10-12,62,4), MS Würzburg Universitătsbibliothek M.p.j.f.m.2 (C. 1,27,1,37-1,27,2,16 and 2,43,3-2,51,2), MS Stuttgarth Württemb. Staatsbibl. Cod. fragm. 62 (C. 4,20,12-21,11).

This article summarises details of manuscripts identified since the standard 1877 edition of the Justinian Code and containing additions to or revisions of headings and subscripts. The manuscripts are: P. Oxy. XV 1814 (CJ 1,11,1-1,16,11 [first edition]), MS Cologne GB Kasten B no. 130 (CJ 3,32,4-12), PSI XIII 1347 (CJ 7,16,41-7,17,1), P. Rein. Inv. 2219 (fragments of CJ 12,59,10-12,62,4), MS Wüzburg Universitatsbibliothek M.p.j.f.m.2 (CJ 1,27,1,37-1,27,2,16 and 2,43,3-2,51,2), MS Stuttgart, Würtemb. Staatsbibl. Cod. fragm. 62 (CJ 4,20,12-21,11).

I. Introduction - II. Sixth-century manuscripts a) P. Oxy. XV 1814, b) Cologne GB Kasten B no. 130, c) PSI XIII 1347, d) P. Rein. Inv. 2219 - III. The Worzburg fragments - IV. The Stuttgart folio

\section{Introduction:}

Krüger's edition of the Justinian Code, which began to appear in annual fascicles from 1873 , was complete by 1877 . In fact there were two editions: the editio maior, with lengthy introduction and full apparatus criticus, totalling more than 1200 pages; and the editio minor, being volume $I I$ of the Corpus luris Civilis, with an attenuated introduction and abbreviated apparatus ${ }^{\prime}$ ). This latter has remained in print, going through numerous near-identical editions, and so is the most usual resource for scholars. The large edition is much less common, and has only been reprinted once by Keip in a reduced format in 1998 as part of their series celebrating 100 years of the BGB $^{2}$ ). The new Dutch parallel translation of the Code uses Kruger's original 1877 text $^{3}$ ).

Despite Krüger's edition being now 130 years old, the number of new manuscript witnesses for the Code that has emerged is slender, and these are generally short and

) An especial thanks goes to Wolfgang Kaiser for drawing my attention to the Wurzburg and Stuttgart fragments, for supplying digital images of the manuscripts, suggesting additional bibliography and for making suggestions as to the readings of difficult faded passages (although I take sole responsibility for any readings printed). I should also like to thank Michael Crawford and Benet Salway for their advice and assistance.

1) For the publication sequence of the fascicles of both maior and minor, see the bibliography attached to F. Schulz's obituary of Krüger in: ZRG Rom. Abt. 47 (1927) xxxiii-xxxiv.

2) 100 Jahre Bürgerliches Gesetzbuch: Pandektistik 62. Olms-Weidmann for a long time had plans for a two volume reprint. Although this was abandoned, I believe it has been resurrected by Vico.

${ }^{3}$ ) J. E. Spruit/J. M. J. Chorus/L. de Ligt, Corpus Iuris Civilis, Tekst und Vertaling VIl: Codex Justinianus 1-3, Amsterdam 2005 and Corpus Iuris Civilis, Tekst und Vertaling VIII: Codex Justinianus 4-8, Amsterdam 2007. The first of these volumes reflects neither the Oxyrhynchus papyrus of Book One nor the Cologne fragment of Book Three. For criticism of the Dutch project for not reflecting important revisions to Krüger's text, see the review of Codex Justinianus 1-3 by P. Nève in: ZRG Rom. Abt. 125 (2008) 735-739. 
fragmentary, covering only a few constitutions or titles. This is not to say that a new edition is not desirable, and that existing manuscripts could not be used to produce it. Even more important, given that Code manuscripts, other than the incomplete Verona palimpsest, are largely deficient for the Greek constitutions and that the Greek texts have to be restored from later Byzantine legal materials, the production of the new edition of the Basilica and of other legal works in Greek will have a profound effect upon such an endeavour ${ }^{4}$ ). Certainly, with the Code not surviving intact and being to a considerable extent a reconstruction, new manuscripts of the direct Code tradition containing any additional information are at a premium, especially with regard to the headings and subscripts, those elements which became attenuated and then discarded in the high-mediaeval Vulgate tradition. Yet the amount of such material so far known is small. The few instances in which new (post-1877) witnesses provide fresh information on either the headings or subscripts of constitutions are here discussed. First are treated four sixth-century manuscripts. Next come the hitherto unpublished Würzburg fragments, dating from the later eleventh century, from which I publish the titles, headings and subscripts. Finally I look briefly at the late eleventh-century Stuttgart folio. The eleventh-century Vallicelliana fragments are published elsewhere in this volume and the information from them is not repeated here.

The abbreviations used here for manuscripts follow Krüger's apparatus, but the principal ones cited are: $\mathbf{P}=$ Pistoriensis Arch. Cap. 106 (prev. 66); $\mathrm{L}=$ Parisiensis Lat. 4516; $V=$ Veronensis LXII (60), the famous sixth-century palimpsest. The most important of the early-modern printed Code editions and commentaries cited by Kruger is that of Haloander (Nuremburg, 1530).

\section{Sixth-Century Manuscripts:}

This section contains details of four manuscripts, three being papyri from Egypt (one certainly and one possibly being from the First Edition of the Code), and one a palimpsested parchment of unknown origin.

a) P. Oxy. XV 1814 $)\left[\mathrm{CJ}^{1} 1,11,1-1,16,11\right.$; $\mathrm{cf}^{\mathrm{C}} \mathrm{CJ}^{2} 1,11,1-1,18,11$; title rubrics and constitution headings only]

This papyrus, first published in 1922, is well-known for giving us our most detailed glimpse of what the First Edition of the Justinian Code (the Novus Codex) looked like, and should be datable to the short period 529 to 534 . Although it preserves just the rubrics of the titles and the headings of the constitutions of Book I, titles 11 to 16 (=11 and 14-18 of the Second Edition), it gives a good idea of which material was added or subtracted in the later edition (the Codex Repetitae Praelectionis) ${ }^{6}$ ). Most

$\left.{ }^{4}\right)$ For some discussion of and suggestions regarding CJ Greek texts, see B. H. Stolte, The use of Greek in the Theodosian Code, in: A. J. B. Sirks (ed.), Aspects of Law in Late Antiquity, Oxford 2008, 77-94. Among other things, he proposes that the text restored for the lost Greek constitution at CJ 10,16,1 should rather supply the missing Greek law at CJ 1,26,6.

5) M. Amelotti/L. Migliardi Zingale, Le costituzioni giustinianee nei papiri e nelle epigrafi (Legum Iustiniani Imperatoris Vocabularium Subsidia 1), $2^{\text {nd }}$ ed., Milan 1985, 17-23; Corpus Papyrorum Latinarum no. 101; Codices Latini Antiquiores Suppl. no. 1713; R. Seider, Paläographie der lateinischen Papyri II, 2, Stuttgart 1981 , no. 34 .

6) The best discussion setting out the differences between the two CJ editions as revealed by the papyrus is still P. de Francisci, Frammento di un indice del pri- 
famously the so-called Law of Citations was clearly present in the First Edition under the probable title De Auctoritate Iuris Prudentium (CTh 1,4,3 = CJ' 1,15,1), which was, of course, replaced in the Second Edition by the introductory constitutions of the Digest $\left(\mathrm{CJ}^{2} 1,17=\mathrm{C}\right.$. Deo Auctore and $\mathrm{C}$. Tanta). I discuss here the details regarding headings, but also highlight the differences revealed between the Novus Codex and the Codex Repetitae Praelectionis.

CJ' 1,11,1: '[ . . ]odoto' is all that is preserved of the heading of an otherwise unattested constitution. The second text in the index, $\mathrm{CJ}^{1} 1,11,2\left(=\mathrm{CJ}^{2} 1,11,1\right)$, matches CTh $16,10,4$, but the other three Theodosian constitutions before that (CTh 16,10,1-3) are not elsewhere present in $\mathrm{CJ}$, nor do they have an appropriate addressee ending '-odoto' to twin one of them with our mysterious law. The addressee has been restored variously as Theodotus, Diodotus and even Theodorus'). Previously I speculated and rejected the idea that this constitution might represent the lost law of Constantine banning sacrifice mentioned by Eusebius (Vit. Const. 2,45,1) and implied by Constans $\left.(\mathrm{CTh} 16,10,2)^{8}\right)$. Tim Barnes has recently revived this idea ${ }^{9}$. The following text ( $\mathrm{CJ}^{\prime}$ $\left.1,11,2=C J^{2} 1,11,1\right)$ is headed '[imp. Consta]ntin. A. ad Taurum pp.'. Although this is wrong (the emperor is Constantius), it does show that there has been a change of emperor between the two constitutions, otherwise the heading would have been 'Id(em) A.'. Logically therefore, given the subject matter (de Paganis Sacrificiis et Templis), the emperor should be a pre-Constantian Christian emperor, i.e. Constantine, and the otherwise unattested law would have to come from one of the incompletely preserved first five books of the Theodosian Code $\left.{ }^{10}\right)$. Thus Tim Barnes's argument. However, although the first half of $\mathrm{CJ}$ Book One contains only religious, generally Christian, material, there are some rare texts of pre-Christian emperors (CJ 1,9,1-2: both rescripts relating to the Jews). It is not impossible, therefore, that some pre-Christian text was included at this point ${ }^{11}$ ). The most difficult question, however, is not simply what this law was, but why it was it apparently dropped from the Second Edition. There is no trace of it in either the Latin or Greek traditions and derivatives of the Code, whether relating to this title or indeed to any other (if one supposes that it could have been relocated elsewhere in the Second Edition). The only logical conclusion is that the

mo codice giustinianeo, in: Aegyptus 3 (1922) 68-79. Other discussions include $P$. Krüger, Neue juristische Funde aus Ägypten, in: ZRG Rom. Abt. 43 (1922) 560563; L. Wen ger, Die Quellen des rómischen Rechts, Vienna 1953, 572-576; G. G. Archi, Giustiniano legislatore, Bologna 1970, 83-91; G. Purpura, Diritto, papiri e scrittura, $2^{\text {sd }}$ ed., Turin 1999, 142-146.

7 De Francisci, Frammento (n. 6), 71.

8) S. Corcoran, The Empire of the Tetrarchs, rev. ed., Oxford 2000, 315-316. I suggested Theodotus bishop of Laodicea as a possible ecclesiastical recipient.

) He put this forcefully at the 'Constantine and the Late Roman World' conference in York (July 2006).

$\left.{ }^{10}\right)$ Note that the full publication of P. Vindob. Lat. 81 (Codices Latini Antiquiores $X$ 1529) has revealed part of a previously unattested CTh text $F$. Mitthof, Neue Evidenz zur Verbreitung juristischer Fachliteratur im spătantiken Ägypten, in: H. - A. Rupprecht (ed.), Symposion 2003, Vienna 2006, 415-422).

if) As suggested by Caroline Humfress responding to Barnes's paper at the York conference. See also the tentative comments in S. Corcoran, The publication of law in the era of the Tetrarchs: Diocletian, Galerius, Gregorius, Hermogenian, in: A. Demandt et al. (edd.), Diokletian und die Tetrarchie: Aspekte einer Zeitenwende, Berlin 2004,62 n. 26. 
extra law of Justinian under this title added to the Second Edition $\left(\mathrm{CJ}^{2} 1,11,10\right)$ rendered the earlier law obsolete and necessitated its removal, but not the removal of the other earlier laws. The measures contained in the additional law are comprehensively anti-pagan. They penalize those who do not convert to Christianity, and most notably ban teaching by those 'infected with Hellenic madness', who can no longer receive public salaries even if holding teaching posts under imperial grant. Given the already extensive legislation banning pagan cult and sacrifices, the missing law can hardly have simply said the same, since why would it have been chosen for the First Edition, only to be dropped from the Second? Rather it must have recognized the validity of some form of pagan right of property holding or practice. The most notorious feature of Justinian's new law was precisely the ban on pagan teaching, so that it is seen as not unrelated to the closure of the philosophical schools at Athens (529). I wonder, therefore, whether the text in question was a third-century rescript or letter to one of the heads of the schools or some similarly interested person regarding the property, rights or succession of the schools ${ }^{12}$ ). Of course, it could instead have been a Constantinian text recognizing the continued existence of these philosophical schools, or otherwise acknowledging or protecting the rights of pagans in a more general fashion.

$\mathrm{CJ}^{1} 1,11,4=\mathrm{CJ}^{2} 1,11,3$ : This text is addressed to Mactobius and Proclianus. The latter is recorded in the Second Edition as simply vicarius, but in the index here as 'vic. $v$ prov' (i.e. vicarius quinque provinciarum [Viennensis]), which matches the description in the source text, CTh $16,10,15$ (where the other addressee Macrobius is also styled vicar of the Spains).

$\mathrm{CJ}^{\mathbf{3}} 1,11,8=\mathrm{CJ}^{\mathbf{2}} 1,11,7$ : The index seems to indicate that the praenomen of the addressee, Palladius, was M(arcus), although no names beyond Palladius are attested elsewhere, and praenomina have largely disappeared by the fifth century ${ }^{13}$ ). One would expect Fl(avius), if anything. However, the underdotted ' $M$ ' read by the editors looks rather too closed on the second loop, so perhaps this is not an $\mathbf{M}$ at all. The abbreviated nature of Code headings means that the fantastic polyonomy of late antique office-holders is usually concealed. Thus John the Cappadocian appears in the Code simply as Iohannes $p p$, whereas a recently published inscription reveals a full and elaborate nomenclature ${ }^{14}$ ).

$C^{\prime} 1,11,10=\mathbf{C J}^{\mathbf{2}} 1,11,9$ : In Krüger's edition, the (probably original) Greek of this and the following constitution has been restored into the Code (both as to text and location) from the Nomocanon ${ }^{15}$ ) and various Basilica manuscripts ${ }^{16}$ ), although

12) For imperial letters and rescripts on such matters, see J. H. Oliver, Marcus Aurelius and the Philosophical Schools at Athens, in: The American Journal of Philology 102 (1981) 213-225 and R. van Bremen, Plotina to all her friends: the letter(s) of the empress Plotina to the Epicureans in Athens, in: Chiron 35 (2005) 499-532.

${ }^{13}$ ) See The Prosopography of the Later Roman Empire [=PLRE] II, Palladius 9 and R. W. B. Salway, A survey of Roman onomastic practice from $c$. $700 \mathrm{BC}$ to $\mathrm{AD}$ 700, in: Journal of Roman Studies 84 (1994) 130-131.

14) L'Année Epigraphique 2004, 1410 = Supplementum Epigraphicum Graecum 54 (2004) no. 1178: Fl. Marianus Michael Gabriel Archangel Ioannes (perhaps also Eutropius).

15) Nomocanon 6,3 with 1,10;4,4; 4,7 (B. Pitra, Iuris Ecclesiastici Graecorum Historia et Monumenta, Rome 1868, vol. II, 469, 509-510, 517).

$\left.{ }^{16}\right)$ The text survives principally in BN Coislin. 151 and Grec. 1352 and appears in Heimbach's edition (1,1,19-20 [vol. I, 15-16]). These manuscripts, however, 
lacking heading and subscript. That the first word at least is the correct opening of the Greek text is confirmed by its citation in the Collectio Tripartita $\left.(1,3 \text {. parat. } 30)^{17}\right)$. The First Edition index gives a Greek heading, which confirms that the original language of this text in the Code was Greek, and it records Anastasius as the issuer to an

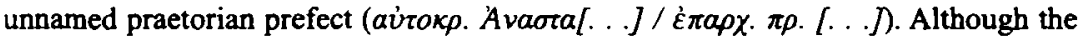
attribution of this law to Anastasius is recognized by various writers (e.g. Bury and Jones) ${ }^{18}$ ), it is surely a sign of reliance upon Krüger's editions that many scholars, even Anastasian specialists, have failed to note $\mathrm{it}^{19}$ ). Most scholars, who cite it, continue to attribute it to Justinian ${ }^{20}$ ). The most spectacular oversight is that of Frank Trombley, who, by overlooking the papyrus and misunderstanding both the ancient and modem editions of the Justinian Code, spends a dozen pages fruitlessly arguing for the attribution of the 'quasi-Justinianic' laws (CJ $1,11,9-10)$ to Zeno in the early $480 \mathrm{~s}^{21}$ ).

are no longer considered to represent the true Basilica version of Book I, and so here probably give the original $C J$ text, but without headings and subscripts. See K. E. Zachariae von Lingenthal, Beiträge zur Kritik und Restitution der Basiliken, in: Mémoires de l'Académie impériale des sciences de St.-Pétersbourg, 7 sér., XXIII.6 (1877) 1-39 [repr. in Kleine Schriften zur romischen und byzantinischen Rechtsgeschichte, Sammlung der in Zeitschriften und Serienwerken erschienenen selbstăndigen Abhandlungen 1840-1894, Band I: 1840-1879, Leipzig 1973, 575-613]; cf. Scheltema, Basilicorum Libri LX, ser. A., vol. I, p. XI. The short parallel Basilica passages are restored by Scheltema (Bas. Ser. A vol. I, p. 3) as follows: Bas. 1,1,14 from Pitra, Iuris Ecclesiastici (n. 15), 609; Bas. 1,1,15-16 from Synopsis Basilicorum E, XIX, 1 (lus graecoromanum vol. V, 274) with Bas. Scholia 21,1,45,5 (ser. B vol. IV, p. 1269).

i) N. van der Wal/B. H. Stolte, Collectio Tripartita: Justinian on Religious and Ecclesiastical Affairs, Groningen 1994, 52.

19) J. B. Bury, History of the Later Roman Empire, from the death of Theodosius I to the death of Justinian (A. D. 395 to A. D. 565), London 1923, II, 396 n. 2 (a last minute note added following the publication of the papyrus, as he originally attributed the law to Justinian on p. 367); E. Stein, Histoire du Bas-Empire II, Paris 1949, 330 n. 8; A. H. M. Jones, The Later Roman Empire 284-602, Oxford 1964, 938 with n. 2.

${ }^{19}$ ) It is ignored in C. Capizzi, L'imperatore Anastasio I (491-518): Studio sulla sua vita, la sua opera e la sua personalità (Orientalia Christiana Analecta 184), Rome 1969. It is also omitted from her list of Anastasius's legislation (drawn from Krüger) by F. K. Ha arer, Anastasius 1: Politics and Empire in the Late Roman World (ARCA 46), Liverpool 2006, 285-287.

20) Thus P. R. Coleman-Norton, Roman State and Christian Church, London 1966 , vol. 3, 1026-1027 no. 583; K. Noethlichs, Kaisertum und Heidentum im 5. Jahrhundert, in: J. van Oort and D. Wyrwa (eds.), Heiden und Christen im 5. Jahrhundert, Louvain 1998, 21-23; M. Maas, John Lydus and the Roman Past, London 1992, 71 n. 17; M. Meier, Das andere Zeitalter Justinians: Kontingenzerfahrung und Kontingenzbewaltigung im 6. Jahrhundert n. Chr., Göttingen 2003, 202 n. 484 and p. 206; E. J. Watts, Justinian, Malalas, and the end of Athenian philosophical teaching in A. D. 529, in: Joumal of Roman Studies 94 (2004) 179-182, repeated in City and School in Late Antique Athens and Alexandria, Berkeley 2006, 138-142; cf. C. Wildberg, Philosophy in the age of Justinian, in: M. Maas (ed.), The Cambridge Companion to the Age of Justinian, Cambridge 2005, 332.

21) F. Trombley, Hellenic Religion and Christianization c. 370-529, vol. I (Religions in the Greco-Roman World 115/1), Leiden 1993, 81-94. Even some of those who reject Trombley's arguments on this point have failed to note the papyrus; e.g. G. Fowden in: Journal of Roman Studies 85 (1995) 342-343; and Watts, Justinian, Malalas (n. 20), 179 n. 82. Others are aware of his error - thus J. Beauca mp, Le philosophe et le joueur: la date de la 'fermature de l'école d'Athènes', in: Mélanges 
$\left[C J^{2} 1,11,10\right]$ : This text is only known in a Greek version restored into the Code together with the previous constitution from later Byzantine works ${ }^{22}$ ). Its absence from the papyrus shows that it was added to the Second Edition. Thus, whatever its exact heading and subscript details might have been, the issuing emperor is clearly Justinian and the date between April 529 and November 534. The law is a comprehensive anti-pagan measure, trying to enforce conversion, with severe penalties for non-compliance. Since it includes a ban upon pagan teaching, which also includes the prohibition of the receipt of a public salary or the holding of a post under an imperial grant ${ }^{23}$ ), it is usually connected with Malalas's report of a law banning philosophy and astronomy teaching at Athens in the consulship of Decius $\left.(529)^{24}\right)$. Further, since Malalas also includes the banning of dice-games in his account of the law, this may also be related to fragments of a law regulating such games from September 52925). Watts, however, has recently argued that the surviving legislation is a far from perfect match with Malalas's account, which should therefore refer to another missing law. He suggests instead that the Code law should be dated to 531, thus precipitating the flight of Damascius and his colleagues to the philosophy-friendly court of the newly enthroned Chosroes $\mathrm{I}^{26}$ ). Whatever the exact date of the law, certainly some feature of this law's content must have contradicted or overruled $C \mathrm{JJ}^{\prime} 1,11,1$ in such a way that the latter had to be dropped from the Second Edition, as I discuss above.

$\left[C \boldsymbol{J}^{2} 1,12\right.$ and 1,13]: These two titles (on asylum in church and manumission in church) are missing from the papyrus. However, since they mostly contain pre-529 material, which was otherwise rendered invalid in its original form on the publication of the Novus Codex, the texts they contain must have been relocated here from elsewhere in the Code. For instance, it seems likely that CTh 4,7,1, the source text for CJ 1,13,2, was probably placed in Book Seven with other material relating to manumission and freedmen ${ }^{27}$ ). Then, since Justinian enacted a series of measures sweeping away the vestiges of the Augustan manumission laws after the publication of the Novus Codex ${ }^{28}$ ), the earlier part of Book Seven needed to be radically

Gilbert Dagron, Paris 2002, 25 n. 21 and A. D. Lee, The eastern empire: Theodosius to Anastasius, in: Averil Cameron et al., The Cambridge Ancient History XIV, Cambridge 2000, 50 n. 109.

$\left.{ }^{22}\right)$ See notes 15 and 16 .

${ }^{23}$ ) Similar measures preventing pagans or heretics from teaching or receiving public salaries are attested also at $C J 1,5,18,4$, in a law which must be of very similar date (occurring just before one addressed to Demosthenes ppo).

24) John Malalas, Chronographia 18,47 (ed. Thurn, Berlin 2000, 379). Note that the old edition of Dindorf printed a text that referred to law teaching, while the new Thurn edition follows a manuscript that refers to astronomy. The variant reading was already noted by $\mathrm{R}$. Scott, Malalas and Justinian's codification, in: Byzantine Papers, Canberra $1981,22$.

25) CJ $1,4,25$ and $3,43,1$.

26) See Watts, Justinian, Malalas (n. 20), 181 and idem, City and School (n. 20), 138-140. He also misses the Anastasian attribution of $\mathrm{CJ} 1,11,9$ and so dates that as well to 531 .

${ }^{27}$ Thus CTh 4,8,4 = CJ 7,16,42; CTh 4,8,6 = CJ 7,18,3; CTh 4,9,1 = CJ 7,10,7.

${ }^{28}$ The post-First Edition manumission laws are: CJ 7,2,15; 7,4,14-17; 7,5,1; $7,6,1 ; 7,7,1-2 ; 7,15,1-3 ; 7,17,2$. There are only two pre-529 laws of Justinian (CJ $7,3,1 ; 7,17,1)$ in this part of the Code, and several of the titles are clearly new (e.g. CJ 7,5 and 7,6 ). 
revised. This may have provided the background to a decision for the manumission in church laws to be relocated to the end of the ecclesiastical section of Book One in the Codex Repetitae Praelectionis. This internal rearrangement also raises the question of whether the bilingual constitution CTh 9,45,4, of which only the Greek version was present at $C J 1,12,3$ in the Second Edition, lost its Latin version on being placed in the First Edition, or only on re-location in the Second Edition ${ }^{29}$ ). We must remember that much of the extensive material added to the first titles of Book One in the Second Edition was in Greek and reflects the erosion of Latin as the language of current law ${ }^{30}$ ).

$\mathrm{CJ}^{1} 1,12,1=\mathrm{CJ}^{2} 1,14,1$ : The index does not record the additional name 'Septimius' for Bassus $p u$, which seems therefore to have been edited out when the Theodosian text $(\mathrm{CTh} 1,2,3)$ entered $\mathrm{CJ}$. However, the presence of additional names at $\mathrm{CJ}^{\prime}$ $1,16,1-2$ suggests that these were not routinely suppressed.

$C J^{1} 1,12,7=C J^{2} 1,14,7$ : Although this heading is lost in a lacuna, there does not appear to have been space for the full form of the heading Idem AA. Cym pp. et consuli designato. The last three words were perhaps omitted.

$C J 1,12,10=C^{2} 1,14,10$ : The Greek heading to this constitution was restored by Kriger on the basis of the Latin subscript date (February 468, from Haloander's edition). The papyrus confirms both the emperors (Leo and Anthemius) and the language (Greek), with the unsurprising addition of $\dot{\varepsilon} \pi a \rho x$. as recipient, presumably denoting one of the praetorian prefects. Nicostratus is attested as ppo Orientis between March and September $\left.468^{31}\right)$. Seeck suggested him as the recipient of this law by association with $\mathrm{CJ} 12,21,7$ (in Latin) ${ }^{32}$ ), although it is now clear that the Code version of $\mathrm{CJ}^{\prime} 1,12,10$ was in Greek, even though the surviving Greek at $\mathrm{CJ}^{2} 1,14,10$ is a version restored from the Basilica and is not necessarily the original tex $t^{33}$ ).

[CJ 1,14,12]: This law is dated to October 529, so that its omission from title 1,12 of the First Edition index is no surprise.

$\mathrm{CJ}^{1} 1,13,2=\mathrm{CJ}^{2} 1,15,2$ : Krugger restores Justin and Justinian into the heading of this constitution on the basis of Nov. 124,4 (making the year 527), while the main text, not necessarily the original version, is taken from the Basilica $a^{34}$. The papyrus confirms the original language as Greek, and even gives the numeral $\beta$ (the only constitution number in the surviving index). However, the heading is frustratingly fragmentary and is the only place where the original reading of the papyrus has been substantially revised. The first part is now taken to open with the unusual formula (for the Code

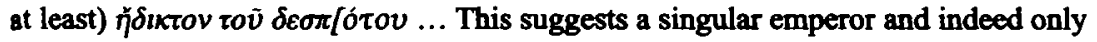

$\left.{ }^{29}\right)$ Stolte, The use of Greek (n. 4), 80 n. 7 confirms Krager's views that the Second Edition contained only the Greek version, but does not consider the issue of differences between the two editions of the Code.

${ }^{30}$ ) See T. Honoré, Tribonian, London 1978, 39, 58-59 and 124-138. The contrast is much more marked in the composition of the Novels from 535 onwards. For the connection of this phenomenon with John the Cappadocian's tenure of the prefecture of the East, see C. Kelly, Ruling the Later Roman Empire, Cambridge/MA 2004, 32-36.

31) PLRE II, Nicostratus 2.

32) O. Seeck, Regesten der Kaiser und Päpste, Stuttgart 1919, 138.

33) Basilica 2,6,15 (Schelte ma, Ser. A., vol. 1, p. 77).

34) Basilica 2,6,19 (Schelt tema, Ser. A., vol. 1, p. 77). 
Justinian's name is in part preserved. If Justin's name stood in the gap, it is not clear how the whole inscription should be reconstructed. However, since Novel 124, both in its Greek original and in the Latin of the Authenticum (117), clearly means only a single law of both emperors (not two separate laws, one of Justin and one of Justinian), it is the papyrus index that must be in error in using the singular.

[CJ 1,16,2]: Kriger ad loc. records the Pithou brothers as stating that a Greek constitution should stand at this point $\left.{ }^{33}\right)$. However, the papyrus index only gives one constitution, $\mathrm{CJ}^{\prime} 1,14,1\left(=\mathrm{CJ}^{2} 1,16,1\right)$, under this title (de Senatus consultis). If a constitution is indeed missing, it must have been a Greek constitution of Justinian dating after April 529 and added into the Second Edition.

$\mathbf{C J}^{\prime} 1,15,1$ : This law is addressed by Theodosius and Valentinian to the Senate on the matter of the authority of the jurists' writings and must be the so-called 'Law of Citations' (CTh 1,4,3). It was superseded in the Second Edition by the Digest constitutions under $C^{2} 1,17$. It seems likely that the title rubric in the First Edition should be restored as [De auctoritate] iuris [prudentium], which was adapted and expanded in the Second Edition into De veteri iure emucleando et auctoritate iuris prudentium qui in digestis referuntur.

$\mathrm{CJ}^{1} 1,15,2$ : This heading records an otherwise unknown law on the authority of the jurists addressed by Justinian to the praetorian prefect Menas, and so datable between June 528 and April 52936). Like CJ' 1,15,1 (CTh 1,4,3) it was superseded in the Second Edition by the Digest constitutions under $\mathrm{CJ}^{2} 1,17$. While the content of the law is, of course, irrecoverable, several suggestions have been made as to its general purpor $t^{37}$ ). One is that it regulated the relationship between the new Code and the juristic writings, and could even have been an extract from $C$. Summa, which was indeed addressed to Menas. Alternatively, it might simply have directed that problems of juristic interpretation be referred to the emperor for resolution. It might even have been the constitution that set up the new project of the Quinquaginta Decisiones, which was designed to settle various long-standing and intractable areas of juristic disagreement. At the least, it shows that Justinian was still working essentially within the framework of the Law of Citations and had not yet conceived the ambitious plan to recompile and re-edit the juristic writings into a single new work.

$\mathrm{CJ}^{1} 1,16,1=\mathrm{CJ}^{2} 1,18,1$ : The index records an extra name Iulius for the recipient, the soldier Maximus.

$C^{\prime} 1,16,2=C^{2} 1,18,2$ : The index confirms the extra name 'Sextius' ('[S]esxt.') for luvenalis, not attested in other $\mathrm{CJ}$ manuscripts, but preserved by an alternative route in the Breviary Gregorianus ${ }^{38}$ ). It is also notable that the incorrect idem aug. of the other CJ manuscripts (suggesting the emperor is Caracalla) is also present in the

${ }^{35)}$ See P. and F. Pithou, Observationes ad codicem et novellas Justiniani imperatoris per Iulianum translatas, Paris 1689, 255.

36) PLRE II, Menas 5.

${ }^{37}$ See de Francisci, Frammento (n. 6), 74-75; P. Bonfante, Frammento del Codice giustinianeo, in: BIDR 32 (1922) 277-282 [= Un papiro di Ossirinco e le quinquaginta decisiones, in: Scritti Giuridici Varii IV, Rome 1925, 132-135]; We nger, Quellen (n. 6), 575; Purpura, Diritto (n. 6), 145-146. For a recent survey and discussion of the question, see C. Rus so Ruggeri, Studi sulle Quinquaginta Decisiones, Milan 1999, 82-96.

38) Codex Gregorianus Visigothicus 3,8,1 (FIRA II, 661). 
papyrus, although the emperor must be Gordian III (again correctly recorded in the Breviary Gregorianus).

$\mathrm{CJ}^{1} 1,16,5=\mathrm{CJ}^{2} 1,18,5$ : This is the first constitution of the First Tetrarchy that one reaches in the Code. Krüger printed the heading as Idem AA et Constantius et Maximianus nobilissimi Caesares Martiali, recreated on the basis of two of the mediaeval witnesses, the Summa Perusina and R (Berolinensis 273). The papyrus version here clearly used only the standard simple form: Idem AA et CC Martiali. The only other Code heading to refer to the two Caesars by name is $1,22,2$, on the authority of Haloander and Gratian's Decretum (C. XXV q.2 c.16). By contrast the few Second Tetrarchy headings are routinely fulsome (CJ $3,12,1 ; 5,42,5 ; 6,9,7)$.

b) Cologne GB Kasten B no. 130 [CJ 3,32,4-12]

This palimpsest fragment, dated to the sixth century, was published in $1890^{39}$ ). In a rare interference with his original work, Krüger actually added information from this into the ninth edition of the editio minor in 1915 (pp. 138-9), which was repeated in subsequent editions, including the most recent reprint of $1997^{40}$ ). By some oversight, however, the thirteenth edition of 1963 went back to the eighth edition of 1906 and so all references to the Coloniensis are missing (although it is still listed among the manuscripts on p. vi). Even so, in those editions which do reflect Krüger's added references, the Coloniensis is only noted five times in the apparatus, and only in one case is the text changed and the Cologne reading printed.

CJ 3,32,9: Editions reflecting the Cologne manuscript have the date as iiii $k$. Mart., replacing iii $k$. Mart. of the earlier editions, which had followed the reading of Haloander ${ }^{11}$ ). In most other cases the Cologne readings support Kruger's existing text, except for CJ 3,32,4, where xii $k$. Nov. is taken from Haloander against the $x i k$. Nov. of the Coloniensis and $\mathrm{P}$ (the Pistoriensis). Krüger clearly adopted the principal that Roman numerals are more likely to lose that acquire new elements, so that the longest numerals are generally preferred, especially when deriving from an early manuscript witness.

c) PSI XIII 134742) [CJ 7,16,41-7,17,1]

CJ 7,16,41: The subscript is missing in the rest of the manuscript tradition, but although this papyrus clearly shows that there was a subscript, it only survives as tracce indecifrabili.

CJ 7,16,42: The numeral $(\mu \beta)$ next to the heading confirms the numeration of this text.

$\left.{ }^{39}\right)$ G. Gundermann, Das Kölner Fragment des Codex Justinianus, in: Rheinisches Museum für Philologie n. F. 45 (1890) 361-370. See also Codices Latini Antiquiores VIII 1167 and G. Dolezalek, Repertorium manuscriptorum veterum Codicis Iustiniani, Frankfurt 1985, I, 229.

${ }^{40}$ ) This last reprint has not been given an 'edition' number, being simply described as a reproduction of the eleventh edition of 1954 , from which latter, incidentally, the list of interpolations inserted by Krüger as an addendum and in the notes to the 1915 edition was removed by Kunkel.

$\left.{ }^{41}\right)$ The Latin text in the Dutch translation prints iii $k$. Mart. following Krüger's original edition (Spruit et al., Corpus Iuris Civilis VII [n. 3], 570).

42) Amelotti/Migliardi Zingale, Le costituzioni giustinianee (n. 5), 27-31; Corpus Papyrorum Latinarum no. 99; Codices Latini Antiquiores III 293; Seider, Palăographie (n. 5), no. 35. 
d) P. Rein. Inv. 221943) [fragments of CJ 12,59,10-12,62,4]

This papyrus furnishes what is probably the second surviving witness to the First Edition of the Code (the Novus Codex). This identification may be made for two reasons. First, the absence of $\mathrm{CJ} 12,60,7$, which must therefore be a Second Edition supplement. Secondly, although less surely, the presence of abbreviations in the text, which were specifically banned from the Second Edition by C. Cordi 5 , mirroring a similar rule for the Digest (C. Tanta $22=$ CJ 1,17,2,22).

[CJ 12,60,7]: This text is only known in a Greek version restored into the Code from a now lost Basilica manuscript ${ }^{44}$ ). Its absence from the papyrus shows that it was added into the Second Edition. Thus, whatever its exact heading and subscript details might have been, the issuing emperor is clearly Justinian and the date between April 529 and November 534.

CJ 12,62,3: The subscript, missing in the rest of the Code tradition, is partially preserved and may be restored as: [Diocl. III et] Max. A. cons. $=287$, the only consulship that makes any sense of the surviving letters for a constitution with a heading naming the issuers as Diocletian and Maximian ${ }^{45}$ ).

\section{The Würzburg Fragments:}

The manuscript treated here is Würzburg Universitătsbibliothek M.p.j.f.m.2, which was first discussed in print in $1988^{46}$ ). In many ways it is very similar to the Vallicelliana fragments (Carte Vallicelliane XII.3) published elsewhere in this volume. Like those, it comprises only two folios, somewhat damaged by later reuse, with trimmed edges and the ink faded in places, but contains a complete sequence with intact headings and subscripts for the sections it covers, namely $\mathrm{CJ} 1,27,1,37-1,27,2,16$ and $2,43,3-2,51,2$. The script is romanesca, and, although previously dated to the ninth or tenth centuries, should probably belong to the third quarter of the eleventh ${ }^{47}$ ). Thus. like the Vallicelliana it represents a tradition of copying the complete Code, rather thar. the eleventh-century Lombard practice of excerpting then re-expanding, which led tc the mediaeval Vulgate ${ }^{48}$ ). Like the Vallicelliana, the titles and constitutions are num-

43) Amelotti/Migliardi Zingale, Le costituzioni giustinianee (n. 5), 24-26 Corpus Papyrorum Latinarum no. 100; Codices Latini Antiquiores V 700; Se ider Paläographie (n. 5), no. 17.

4) Basilica 56,17,61 (Schelt ema, ser. A vol. VII, pp. 2594-2595), from J. Cui acius, Ad tres postremos Codicis Justiniani libros commentarii, in: Opera Omnia Naples 1758, vol. II, col. 1009; with Tipucitus 50,14,11 (= Vol. 5, Vatican 1957, 4" I. 25).

45) For the consulships in the joint reign of Diocletian and Maximian, see R. S Bagnall et al., Consuls of the Later Roman Empire, Atlanta 1987, 104-119.

46) R. Weigand, Fragmente der römischen Rechts in der Universitätsbibliothel Würzburg, in: ZRG Rom. Abt. 105 (1988) 784-785; cf. W. Kaiser, Die Epitomı Iuliani, Frankfurt am Main 2004, 703-704.

47) Thus A. Ciaralli, Produzione manoscritta e trasmissioni dei testi di natur: giuridica fra XI e XII secolo: due esempi, in: V. Colli (ed.), Juristische Buchproduk tion im Mittelalter, Kolloquium 25. bis 28 Oktober 1998, Frankfurt 2002, 90-92; cf V. B rown, A second new list of Beneventan manuscripts (IV), in: Mediaeval Studie: 61 (1999) 329. The earlier date is given by Weigand, Fragmente (n. 46), 784-785.

${ }^{48}$ ) C. Radding/A. Ciaralli, The Corpus Iuris Civilis in the Middle Ag es: Manuscripts and Transmission from the Sixth Century to the Juristic Reviva (Brill's Studies in Intellectual History 147), Leiden 2007, ch. 5; cf. C. Radding Reviving Justinian's Corpus: the case of the Code, in: P. Andersen et al. (eds.) 
bered. The title numeration sequence is correct, and does not reflect the additional title created in some mediaeval manuscripts, with a subsequent effect upon the Vulgate tradition, by the insertion of a repeat title heading at $\mathrm{CJ} 2,7,20=2,8,1$. Greek rather than Roman numerals are used for both the title and constitution numbers. In this feature the manuscript differs from the Vallicelliana, but is similar to a tenth-century manuscript now at Munich, Bayerische Staatsbibliothek $\mathrm{Clm} .6375^{49}$ ). Note that although this Munich manuscript too gives a complete sequence for the section of the Code that it covers, including full headings and subscripts (CJ 3,12,2-3,17,1), scholars including Mommsen, Krüger, Conte, and Radding and Ciaralli consider that it was copied only by inadvertence, being the protecting outer leaves of the main work whose reproduction was intended, Eusebius-Rufinus, Historia Ecclesiastica ${ }^{\text {s0 }}$ ). Because the portion of the Code covered by the Würzburg fragments originally contained no Greek constitutions, it is impossible to tell in what manner extensive Greek passages were treated in the manuscript as a whole.

Unfortunately, unlike the Vallicelliana fragments, the Würzburg text covers constitutions whose subscripts were already preserved, even if only from a single source. Therefore, just one subscript is entirely new (CJ 2,46,2). However, given the small number of witnesses to the subscripts, it seems best to print here the Wurzburg subscripts (plus also the title rubrics and constitution headings, both with their surviving Greek numerals), with brief comments on their convergence or divergence from the other known sources. The main text of the constitutions does not differ significantly from Krüger's edition or the variants he cites from other manuscripts, and in only one place do I comment on a clause not otherwise attested, but almost certainly added in error (CJ 2,44,4).

Würzburg Universitätsbibliothek M.p.j.f.m. 2 folio Ir col. 1

On this folio, only parts of the subscript to $C J 1,27,1$ and the heading to $1,27,2$ have been preserved.

CJ 1,27,1: Subscript: emissa lex $\cdot k \cdot a p r \cdot[\ldots]$ no pp $\cdot a \cdot$ iiii $\cdot$ etpaulino uncc conss. (1st April 534)

Kriger printed 'emissa lex Constantinopoli dn. Iustiniano pp. A. iiii et Paulino vc. conss.', taking 'emissa lex' from $C$, the place and emperor from Contius ${ }^{51}$ ), and inferring the consulship. The new text provides the diurnal date (1" April) and confirms much of the rest, although there is a lacuna resulting from the trimming of the parchment. The full subscript could now be restored as :

Emissa lex k. Apr. Constantinopoli d.n. Iustiniano pp A. IIII et Paulino v.c. conss.

CJ 1,27,2: Heading: [Id. A. Belisario] $\mathrm{mag} \cdot \mathrm{mil} \cdot$ peroriente $(\mathrm{m}) \cdot$

Law Before Gratian: Law in Westem Europe c. 500-1100, Copenhagen 2007, 3550.

49) This is F in Krüger's apparatus. See the description by Dolezalek, Repertorium (n. 39), I, 307.

so) Th. Mommsen, Juristische Schriften II = Gesammelte Schriften II, Berlin 1905, 196-197; Krü ger, CJ editio maior, p. VIII-VIII; E. Conte, Tres Libri Codicis, La ricomparsa del testo e l'esegesi scolastica prima di Accursio, Frankfurt 1990, 16 n. 48; Radding/Ciaralli, Corpus Iuris Civilis (n. 48), 51.

s1) A. Contius, Codicis Dn. Justiniani sacratissimi principis pp Augusti repetitae praelectionis libri XII, Paris 1562 , f. 71 , printing the text as follows: Dat. Constantinop. D. N. Iustiniano PP. 
Folio 2r col. 1

CJ 2,43,3: The heading of this constitution has been lost in the trimming of the parchment.

Subscript : pp $\cdot i i k \cdot i u l \cdot$ peregrino et emiliano conss $\cdot(30$ June 244$)$

The manuscript is hard to read at this point, but seems to match the text given in the other sources (Haloander, PL).

CJ 2,44: $R \mathrm{M} \Delta$ De his qui ueniam etatis impetrauerunt. $R$

CJ 2,44,1: Heading : A IMP Aurel $\cdot a \cdot$ Agothocleti .

Subscript : pp $\cdot$ viii $\cdot k \cdot i u l \cdot$ Aurel $\cdot a \cdot i i i \cdot$ etcapitoliano $\cdot$ cons $\cdot(24$ June 274)

Würzburg matches the other manuscripts (PL) in reading viii $k$. Iul., but Krüger prints the k. Iul. of Haloander. Only Würzburg gives an iteration numeral for Aurelian's consulship, but this must be wrong since it should be II for the year 274 with Capitolinus (not Capitolianus). Aurelian was consul III with Marcellinus in 275 2 ).

CJ 2,44,2: Heading : B IMP $\cdot$ Constant $\cdot a \cdot$ Aduerinu(m)pp

Subscript : pp $\cdot$ iii $\cdot \boldsymbol{k} \cdot$ iun $\cdot$ romae $\cdot$ crispo \& constantio $\cdot$ conss $\cdot(30$ May 321/324) Würzburg matches the Breviary tradition of the Theodosian Code (CTh 2,17,1) and Haloander in recording iii before $k$. Iun., omitted by P and L. 'Constantius' is a slip for 'Constantinus'. The consular iteration for each Caesar is recorded as II (thus 321) in the Breviary tradition and also Haloander, although most modem scholars would emend to III to give the year 324, which matches the period in office of the recipient, the urban (not praetorian) prefect Verinus ${ }^{53}$ ).

CJ 2,44,3: Heading: $\Gamma I M P \cdot I$ Iustinian $\cdot a \cdot$ Menae pp .

Folio $2 r$ col. 2

CJ 2,44,3: The conclusion of this constitution has been lost in the trimming of the parchment.

CJ 2,44,4: The opening of this constitution has been lost in the trimming of the parchment.

Subscript : $d \cdot x i \cdot k \cdot a u g \cdot c p \cdot$ postcons $\cdot$ lamp $\cdot$ ethoresto $\cdot u u \cdot c c \cdot(22$ July 531 [530])

This text is from a law addressed to the Senate, of which other portions occur at $\mathrm{CJ}$ $3,38,12 ; 5,4,24 ; 6,25,7$ and $8,41,8$. Almost all the manuscript and printed sources agree on the diumal date as $\left.x i k . A u g .{ }^{54}\right)$. The Würzburg manuscript is the only one to give the post-consulate of Lampadius and Orestes (531) instead of their consulate (530).

This is the only constitution where there is a significant divergence in the main text. Its first sentence, whose beginning is lost in the trimming of the parchment, can be restored as follows:

[Si quis aliquid dari uel fieri uoluerit et legitimae aetatis fecerit mentionem uel sic absolute dixerit 'perfectae aetatis', illam tantummodo aetatem intellectam esse uideri

52) A. Degrassi, I fasti consolari dell'impero romano, Rome 1952, 73.

53) Seeck, Regesten (n. 32), 173; cf. PLRE I, Verinus 2.

s4) Thus for $C J 3,38,12$, Haloander, $P$ and $L$; for $C J 6,25,7$, Haloander; for $C J$ $8,41,8$, Haloander, V, $P$ and $L$. The exceptions are Haloander on this text $(2,44,4)$, who gives ix $k$ april and Merillius, who prints ' 10 Kalend. August.' for CJ 5,4,24 (E. Merillius, [Opera] Pars Secunda: Expositiones in Quinquaginta Decisiones Justiniani, Naples 1720,8$)$. CJ 4,65,35 and $11,48,21$ are also addressed to the Senate and may be part of this law, but no subscripts for them survive. 
uolu]mus, quae ex uiginti quinque annorum curriculi[s] completur, non [perfectam aetatem legitimam intellege[tur]\} ab imperiali beneficio suppleatur.

The phrase which I have put in brace brackets is attested in no other manuscript, nor in the Basilica, which for this sentence is a word-for-word ( $\kappa \alpha \tau \dot{\alpha} \pi \delta \delta \alpha \varsigma$ ) translation $^{55}$ ). It seems most likely that the additional phrase is a gloss incorrectly copied into the main text.

CJ 2,45: $R$ ME Si maior factus ratum habuerit. $R$

CJ 2,45,1: Heading : A IMPP $\cdot$ diocl $\cdot$ etmax $\cdot a a \cdot e t c c \cdot$ Eutychiano

Subscript : $S \cdot$ viii $\cdot k \cdot$ mart $\cdot a a \cdot$ conss $\cdot(22$ March 293)

The other sources (Haloander, $\mathrm{PL}$ ) all give 'mai.'

CJ 2,45,2: Heading : B ID $\cdot A A \cdot$ etcc $\cdot$ Soteri .

Subscript : $S \cdot$ id $\cdot f e b \cdot c c \cdot$ conss $\cdot(13$ February 294$)$

This matches the other sources (Haloander, PL). The constitution that joins to this one is dated vi id. Feb. (CJ 2,32,1).

$C J$ 2,46: $R$ MS Vbi et apud quem cognitio restitutionis agitanda sit. $R$

CJ 2,46,1: Heading : A IMP - Anton . a . Seu(er)o ·

Subscript : pp $\cdot x v i \cdot k \cdot a p r l \cdot$ laeto $\cdot i i \cdot$ etcereale $\cdot$ conss $\cdot(17$ March 215$)$

This subscript matches the other manuscript sources (PL), but Kruger prints Haloander's date of vi $k$. Dec.

CJ 2,46,2: Heading : B IMPP $\cdot$ diocl $\cdot$ etmax $\cdot$ aa $\cdot$ etcc $\cdot$ Aquilinae

Subscript : $S \cdot x i i i \cdot k \cdot$ octb $\cdot A A \cdot$ conss $\cdot(19$ September 293)

This is the only subscript which is entirely new in the Würzburg fragments. The heading includes the Caesars and so matches the date. The other manuscripts are divided on the presence of the Caesars ${ }^{56}$ ).

CJ 2,46,3: Heading : Г IMP $\cdot$ Iustinian $\cdot A \cdot \operatorname{Ioh}(a n n) i p p \cdot$

Folio 2v col. 1

CJ 2,46,3: Subscript : $d \cdot i i i \cdot k \cdot \operatorname{sept} \cdot c p \cdot$ lamp $\cdot$ ethoresto $\cdot u u \cdot c c \cdot(30$ August 530 [531])

The first part of the subscript is somewhat indistinct, but sufficiently legible. Haloander gives the subscript as: $D$. iii $k$. Sept. post consulatum Lampadii et Orestae vv.cc. (531). PL and Miraeus record the place of issue as Constantinople ( $C a p$.) and make the year the third post-consulate (533). Both post-consulates are possible, as the recipient John the Cappadocian was in office in 531 and 533, although the Code contains few laws from the latter year. However, the Würzburg subscript, in apparently giving the consulate of Lampadius and Orestes (530) rather than a post-consulate, must be in error, since Iulianus was praetorian prefect in 530 , only being succeeded by John the Cappadocian in the following year. Thus the consular date here would have the opposite discrepancy to CJ $2,44,4$. However, the lack of 'conss.' at the end of the subscript may suggest that 'postcons' has dropped out before 'lamp'.

CJ 2,47: $R \mathrm{MZ}$ De reputationibus, quae fiunt in iudicio in integrum restitutionis. $R$

CJ 2,47,1: Heading : IMP $\cdot$ Seuer(us) A Tatiano

Subscript : $S$. sine die et consul .

55) Basilica 10,27,4 (Schelt te ma, Ser. A II, p. 597).

56) With Caesars, C, R; without Caesars, P, L, M and Krigger. 
This subscript matches the rest of the tradition (Haloander, PL). Following the rule laid down in its first constitution (CTh 1,1,1), every law in the Theodosian Code carried a dated subscript. When the Justinian Code came to be compiled, the above subscript was supplied for any texts drawn from the Gregorian or Hermogenian Codes, which lacked a subscript ${ }^{57}$ ).

CJ 2,48: $R$ MH Etiam per procuratorem causam in integrum restitutionis agi posse. $R$

CJ 2,48,1: Heading : IMP $\cdot$ alex a LIciniano

Subscript : pp - exvi $\mathbf{k}$ - oct - pompomano et peregrino - conss - (16 September 231) This subscript is a rather confused version of that known from $\mathrm{P}$ and $\mathrm{L}: P P$ xvik. Oct. Pompeiano et Deligno conss. Krüger prints Haloander's version: D. xiii k. Oct. Pompeiano et Peligno conss. ${ }^{58}$ ).

CJ 2,49: $R \mathrm{M} \Theta$ In integrum restitutione postulata ne quid noui fiat. $R$

CJ 2,49,1: Heading : IMP $\cdot$ aled. a $\cdot$ Secundino militi .

Subscript : pp $x \nu \cdot k \cdot$ gord $\cdot a \cdot$ etaurelio $\cdot$ cons $\cdot(17$ [July?] 239)

This subscript is a corrupt poorly written version with the month missing of that known from other sources (Haloander; plus PL, attached to CJ 2,50,1): PP xii k. Iul. Gordiano A. et Aviola conss. The emperor is wrongly recorded in the heading as Aled for Alexander. Even in the addressee's name the ' $d$ ' appears more like 'cl'.

CJ 2,50: $R \mathrm{~N}$ De restitutione militum \& eorum qui rei publicae causa aufuert. $R$

The last word of the title seems not to carry an abbreviation sign, but was probably intended to stand for abfuerunt (afuerunt in Krïger).

CJ 2,50,1: Heading : IMPP $\cdot$ Seu $\cdot$ etanto aa $\cdot$ Chiloni $\cdot$

Subscript : $d \cdot k \cdot$ nou $\cdot$ lat (erano) etrufin $\cdot$ conss $\cdot(1$ November 197)

This subscript matches the other sources (Haloander; plus PL, attached to CJ 2,49,1), except in using d(ata) in place of $p($ ro $) p($ osita $)$.

Folio 2v col. 2

Much of this column is extremely faded, sometimes illegible.

CJ 2,50,2: The heading and subscript are missing as a result of the trimming of the top of the parchment.

CJ 2,50,3: The heading is lost in the trimming of the parchment.

Subscript : The text is very faded, and I can only securely read conss. Wolfgang Kaiser has suggested to me that Maximo III et Aeliano conss is legible. Haloander gives the subscript as: PP. non. Ian. Maximo II et Aeliano conss.

CJ 2,50,4: The heading is too faded to be certain (beyond the constitution number), but should read something in accord with the otherwise transmitted text: $\triangle I M P$ gord a mestriano.

Subscript : pp? $v i$ ? $k$ ian? gord a etauiola conss. (December? 239)

The text is very faded and the reading of the subscript is not secure. There are at least some resemblences to the subscript as known from Haloander, which is: D. xii k. Ian. Gordiano A. et Aviola conss. The similarity in date between this text and CJ 2,49,1

${ }^{57}$ C. Haec 2; C. Summa 3. See M. U. Sperandio, Codex Gregorianus: origini e vicende, Naples 2005, 60-67.

${ }^{58}$ ) The consul's name is properly Paelignianus. See Degrass i, I fasti (n. 52), 64. 
(allowing for Ian/lun confusion), and the fact that the addressee of 2,49,1 and 2,50,5 are both Secundinus miles suggested to Krüger that the addressees of 2,50,4-5 should be swopped, so that $2,49,1$ and $2,50,4$ become parts of a single rescript addressed to Secundinus in 239 (June or December). But note that CJ 2,52,2 of October 238 is also addressed to a Secundinus miles and CJ $8,44,14$ of July 239 to a Secundinus.

CJ 2,50,5: Heading : E ID $\cdot a \cdot$ Secundino militi .

Subscript : pp vii $\cdot$ id mai $\cdot$ sauino etuenu ? conss. ${ }^{59}$ ) (9 May 240)

The text is rather faded, but appears (if correctly read) to differ only a day from that transmitted by Haloander, which reads: PP. vi id. Mai. Sabino et Venusto conss. Similarly the addressee is consistent with Secundino militi recorded in other sources, and so does not provide any manuscript authority for swopping the addressees of this and the previous constitution.

\section{CJ 2,50,6: Heading : S IMPP ualer et gall Germano centurioni}

Subscript : pp $\cdot i i i \cdot$ non $\cdot$ aprl $\cdot$ ual $\cdot i i \cdot v \cdot$ conss $\cdot(3$ April 254 [265?])

The diurnal date differs by one stroke from the 'iiii non. April.' of Haloander. Gallienus is missing from the subscript, with only the mysterious abbreviation or numeral ' $v$ ' before conss. However, Valerian's consulship is recorded as II, which confirms the usually accepted year for this text, $254^{60}$ ). Valerian and Gallienus shared the consulship three times: II and [I] in 254, III and II in 255, and III and III in 25761). Another possibility is that the consulship represented is that of 265: Valeriano II et Lucillo conss. ${ }^{62}$ ).

CJ 2,50,7: Heading : Z IMPP $\cdot$ diocl $\cdot$ etmax $\cdot a a \cdot e t c c \cdot$ Marinae $\cdot$

Subscript : pp $\cdot$ non $\cdot f e b \cdot a a \cdot$ conss (5 February 293)

Haloander gives D. non. Febr. CC conss. (i.e. 294). There is no way of deciding which of these two years is correct. Even if the place of issue or posting had been preserved, that would hardly have helped since Diocletian was at Sirmium in both February 293 and February $294^{63}$ ).

CJ 2,50,8: Heading : H IMP $\cdot$ Iustinian $\cdot a \cdot$ Maenaepp $\cdot$

Subscript : pp ?/d? vii/ii? id apr cp · Decio · conss · (7/12? April 529)

Rather difficult to read, nonetheless this subscript is very close to that otherwise transmitted by Haloander: D. vi id. April. Constantinopoli Decio v.c. cons. However, the twin of this text (CJ 7,35,8) reads $k$. Apr. (PL and Miraeus) and the conjoining text (CJ 6,21,17) iiii id. Apr. (V and Haloander). Kruger suggested that in fact viii id. Apr. was probably correct, so that the combined law would predate the promulgation con-

$\left.{ }^{59}\right)$ conss. appears at the end of the line below the rest of the subscript, after Germano cen-.

$\left.{ }^{60}\right)$ E.g. T. Honoré, Emperors and Lawyers, $2^{\text {td }}$ ed. Oxford 1994, 128, suggesting that the rescript is certainly not in the style of his secretary no. 14, whose tenure of office he dates between July 255 (or possibly July 254) and May 259.

${ }^{61)}$ Degrassi, I fasti (n. 52), 70.

62) Degrassi, I fasti (n. 52), 72. CJ 5,62,17 bears the consular date of 265, while also naming Valerian and Gallienus as joint Augusti in the heading. Note that Valerianus, consul in 265 , was a member of the imperial family (brother to Gallienus), but never a member of the imperial college. See M. Christol, Essai sur l'évolution des carrièrres sénatoriales dans la $2^{c}$ moitié du III ${ }^{\star}$ s. ap. J.-C., Paris 1986, 105-106.

${ }^{63}$ ) T. D. Barnes, The New Empire of Diocletian and Constantine, Cambridge/ MA 1982, 52-53. 
stitution of the First Code (C. Summa, dated vii id. Apr., also addressed to Menas) ${ }^{64}$ ). It is a pity, therefore, that the numeral before 'id.' cannot be read with confidence. It should be noted that there is a gap in the known issue-dates of laws between April and September 529.

CJ 2,51: $R$ NA De uxoribus militum \& (uel Krüger) eorum qui rei publicae causa absunt. $R$

CJ 2,51,1: Heading : A IMP - alex a S Secundinae .

Subscript : pp $\cdot$ iiii $\cdot$ non $\cdot$ dec $\cdot$ alex a $\cdot$ conss $\cdot(2$ December 222 [226?])

Haloander records the subscript as: PP. iii non. Dec. Alexandro A. II et Marcello conss. ( 3 December 226). Thus he gives a similar diurnal date, while rendering the consular date of 226 in a very clear form. As recorded, the Würzburg date could indicate Alexander's first consulship as sole consul in 222 . However, this might simply be over-abbreviation of the full 226 consulate. But note that Haloander likewise recorded the consulship of 226 for CJ 2,50,2 (unfortunately not preserved in this manuscript), which the chronological order of texts led Krüger to emend to that for 222.

CJ 2,51,2: Heading: B IMPP $\cdot$ diocl $\cdot$ etmax $\cdot a a \cdot$ Quintiliano $\cdot$

The text breaks off at the end of the folio before reaching the subscript.

IV. The Stuttgart folio:

A single folio at Stuttgart (Württembergische Landesbibliothek Cod. fragm. 62) preserves part of Book Four, Titles 20 and 21 and probably dates to the second half of the eleventh century ${ }^{65}$ ). It is very different from the Vallicelliana and Würzburg fragments, and matches what one would expect from the epitomizing then re-expanding activity of the eleventh-century Lombard jurists. There are no subscripts, and. in addition to the expected missing Greek constitutions (explicitly noted on one occasion), the Latin constitutions betray some omissions and disorder. There is what must be part of a sequence of running headers noting the book number (quartus). but there are no title or constitution numbers. Although there are several divergences from Krüger's edition in the headings, none seems to represent a superior alternative reading as opposed to fairly obvious instances of miscopying and corruption. The headings are as follows:

CJ 4,20,12. Id. (sc. Honorius et Theodosius) AA. Adhon.

13. Missing Greek constitution.

14. Imp. Zeno Aug. Arch. (Kr. Arcadio).

15-16. Constitutio graeca.

17. Imp. Just. A. Menae pp.

18. Id. A. Menae pp.

19. Id. A. Iuliano pp.

20. Missing Latin constitution.

CJ 4,21. De fide instrumentorum et de amissione eorum et anthapochis faciendis et de his quae sine scriptura fieri possunt.

${ }^{64)}$ P. Krüger, Über die Zeitfolge der im Justinianischen Codex enthaltenen Constitutionen Justinians, in: ZRG 11 (1873) 174.

${ }_{65}$ ) Dolezalek, Repertorium (n. 39) I, 392; C. M. Radding/A. Ciaralli, The Corpus luris Civilis in the Middle Ages: A case study in historiography and medieval history, in: ZRG Rom. Abt. 117 (2000) 303, and Radding/Ciaralli, Corpus Iuris Civilis (n. 48), 107, 152. 
1. Imp. Ant. A. Marcluae (Kr. Marciae [Marchiae]).

2. Imp. Alex. A. Maliano (Kr. Maniliano).

4. Imp. Gord. A. Marciano.

3. Id. A. Eliano.

5. Id. A. Prisco \& Marco militi.

6. Impp. Diocl. \& Max. AA. Lucido (Kr. Luscidae).

7. Missing Latin constitution.

8. Id. AA. Alex. (Kr. Alexandrae).

9. Id. AA. (Kr. et CC.) Eustincto (Kr. Aristaeneto).

10. Id. $A A$. (Kr. et $C C$.) Victorino.

11. Id. $A A$. (Kr. et CC.) Teageni.

Only one of these headings deserves some proper comment.

CJ 4,20,12: Id. AA. Adhon.

In the rest of the manuscript tradition there is no recipient. The Theodosian source text gives Ad Senatum (CTh 9,6,4), as does one of the conjoining texts (CTh 4,10,3 [from the Breviary] $=\mathrm{CJ} 6,7,3)$. The other conjoining constitutions give the full and elaborate consulibus, praetoribus, tribunis plebis, senatui salutem dicunt (CTh 4,10,2 $=\mathrm{CJ}$ $9,1,21 ; \operatorname{CTh} 9,1,19=\mathrm{CJ} 9,2,17$ and 9,46,10). One manuscript (R) of this constitution gives the implausible recipient Filiberto! It is hard to see how any of these could give rise to the heading above. Perhaps 'Ad Sen.' with a half-uncial $\mathrm{S}$ was misread, so that the original $\mathrm{CJ}$ heading could be restored as Id. AA ad Senatum.

London

Simon Corcoran 